\title{
Regional Election Winning Strategy of the Indonesian Democratic Party of Struggle (PDIP) in North Coast Area of West Java Province (Case Study in Subang and Cirebon Regencies)
}

\author{
Muhammad Budiana ${ }^{1}$, Arry Bainus ${ }^{2}$, R. Widya Setiabudi S. ${ }^{2}$, Muradi $^{3}$ \\ ${ }^{1}$ Department of International Relation, Pasundan University, Bandung, Indonesia. \\ 2 Department of International Relation, Padjadjaran University, Bandung, Indonesia. \\ ${ }^{3}$ Department of Political Science, Padjadjaran University, Bandung, Indonesia. \\ m_budiana70@unpas.ac.id
}

\begin{abstract}
The research premise is the idea that there was trend in political participation and voting behavior in Subang and Cirebon Regencies, The two biggest bases of the Indonesian Democratic Party of Struggle (PDIP) in West Java Province. Their power are getting weaker, reflected by the number of their representatives in Representatives Local House. In this research, it is believed that there are three factors which influence those phenomena such as political parties role, figures and identification. The research highlights are the most influential factors on political participation which cause declining support for the party and strategies used by the Indonesian Democratic Party of Struggle (PDIP) to maintain their constituents.
\end{abstract}

Keywords: The Indonesian Democratic Party of Struggle (PDIP), West Java, political parties, figures and constituent.

\section{Introduction}

Political parties are a necessity in countries that implement democracy political system. Political parties become a public interest aggregation and articulation instruments through formal institutions (Almond, 1993). The party bases existence, makes the party generally not only characterize its political movement but also people who later became its followers, mass base or constituency (Joyce, 2008). In Indonesian case, political parties also have a different principle or ideology between each other, namely parties that have Islamic ideology, Islamic mass basis and nationalist party. As Geertz (1983) has also expressed on the results of his research on three Javanese society political groups. His famous differentiation between abangan (syncretists stressing animistic beliefs), santri (followers of a purer Islam) and priyayi (those mostly influenced by a Hinduist aristocratic culture) had a lasting impact on further studies on Java. Although the party is founded on a certain political basis which then has a distinctive movement and mass base, Joyce $(2008$, p. 81) says that in general all political parties have the same goal of securing power and exercising control over the government. In his view it is further argued that in securing power the political parties will compete openly with other parties, and according to Joyce this is a hallmark of the liberal democracy implementation.

Subang and Cirebon Regencies are two areas in the North Coast of West Java, known as the Indonesian Democratic Party of Struggle (PDIP) constituent base. This can be seen from PDIP votes since the first general election post reform movement in 1999. However, the data indicate that there is a tendency that the votes obtained by PDIP continue to fall from 1999 to 2014. Both areas have almost similar characteristics, agricultural areas on peasants and people basis identified as PDIP main bases. The decrease of PDIP members in Local House of Representatives in Cirebon and Subang Regencies is suspected due to a weak political strategy of winning by PDIP in maintaining its constituent base in North Coast Area West Java. This issue may change the claim that North Coast Area is PDIP basis, but it can also affect the west java governor political vote map and vice governor election and the regional head election of Subang and Cirebon Regencies in 2018. Another challenge faced by PDIP and other political parties is political participation negative trend. Data taken from Regional Election Commission in Subang and Cirebon Regencies shows that citizens political participation numbers in the election or presidential election were decreased significantly. In North Coast Area of West Java Province, party identification was empirically hardly discernible from the vote, whereas party identification was less stable than vote choices. It's about the people, not the party. Voters are not loyal to political party, they vote for the person they want irrespective of the political party (Hamid, 2014). It can be seen that party identification is very important particularly facing 2019 presidential election. 


\section{Literature Review}

The constituent winning strategy is concerned with the choice of a person in general election, which means talking about voting behavior. Broadly speaking, there are three models that can explain why someone chooses a particular party. Roth (2009) calling it a sociological, psychological and rational model.

a. The sociological approach: Roth explained that the sociological approach or, more precisely, the structural social approach to elucidating electoral behavior, is logically divided into micro sociological explanations and macro sociological explanatory models. The micro sociological explanation models are associated with sociologist Paul Lazersfeld and colleagues Bernard Berelson and Hazel Gaudet of Columbia University. Therefore, this model is also called the School of Columbia (Columbia School) (Roth, 2009). The microscopic explanation model root derives from social circle theory formulated by Simmel (1989). According to this theory, every human is bound in various social circles, every human being is bound in various social circles, for example family, circle of peers, workplace etc. Lazeersfeld applies this way of thinking to the Elector. A voter lives in a certain context: his economic status, religion, residence, work and age defines social circle that influences voter's decision. Each social circle has its own norm, adherence to these norms leads to integration. However, this context also controls individuals behavior by putting pressure on an individual to adjust, because basically everyone wants to live with peace, without disputing with social environment (Roth, 2009).

Mujani et al. (2012: pp 9-10) explained that a voter chooses a party or candidate for a certain public official because of similarity between voters and party or candidates in sociological characteristics. Associated with social class issues and religious, racial and ethnic sentiments are also believed to be sociological factors that influence how one chooses a political party or a candidate for public office. Specifically, racial and ethnic similarities between voters and public officials candidates tend to influence one's behavior (Roth, 2009, p. 19). The sociological approach has a very powerful influence in analyzing voters behavior. However, this approach has its limitations. Often in modern societies, societies have strong social and spatial mobility, which in turn tends to lead to the relationships breakup. The individuals interconnectedness with multiple social forces (sometimes conflicting with one another) is called cross-pressure. Such inconsistencies can cause a decline in the individual's political interests (Roth, 2009, p. 26). Another limitation is that approach also ignores potential for conflict within each person. That is, everyone has a potential to fight, protest and not be subject to the social system that surrounds it.

b. The Psychological Approach: The Psychological Approach analyzes voter behavior by looking at individual factors. Roth (2009) calls this a term psychological social approach. This approach places individual as the center of attention. There are three focuses of psychological approach, namely: (1) the candidates perception and personal judgment; (2) the themes raised perception and personal assessment; and (3) identification of party or partisanship. This approach, which directly influenced voter choices rather than social structure, as analyzed by the sociological approach (Columbia School), but voters short-term and long-term factors (Roth, 2009, p. 37). Personal perceptions and judgments of the candidate or themes raised (short-term influences) are very influential on elections choices being handed down. In addition, the "psychological membership" in a party that can be measured in terms of party identification variables, contributes to the elections choices, which is a long-term effects result. Therefore, individual electoral decisions are not primarily socially determined structurally, but the result of individuals short-term and long-term effects (Roth, 2009, p. 37).

The psychological social approach seeks to explain what factors influence short-term electoral decisions or decisions taken in a short time. It seeks to be explained through determinant triage, party identification, candidate orientation and issue / theme orientation. Party Identification is often inherited by parents to their children. As we get older, party identification becomes more stable and intensive. Party Identification is a permanent orientation, which does not change from general election to general election. But if a person undergoes a major personal change (e.g. marriage, profession or residence change) or extraordinary political circumstances (such as an economic crisis or war), then the identification of this party may change (Roth, 2009, p. 38). In the same approach, Mujani et al. (2012) explains that a citizen participates in the General Election or Presidential Election not only because of his better socioeconomic conditions, or because he is in a social network, but because he or she is interested in politics, has a feeling close to the certain party (party identity), have enough information to make choices, feel his voice mean, and believe that his choice can contribute to 
improving situation (political efficacy). One of important things associated with the Psychological approach is political engagement (one of which is partisanship). Partisanship is a psychological state, i.e. feeling close to, supportive or loyal attitude to, or self-identification with a particular political party. Partisanship forms a citizen's political identity because citizen has the psychological ability to identify himself with a political party. Therefore, partisanship is usually called the identity of one's party. A partisan is a person who feels himself part of a party or identifies himself with a particular party (Mujani et al., 2012).

The LIPI survey in the 2014 general election shows that religious factor is one of underlying respondents factor consideration in choosing candidates. For respondents who are obedient or disobedient in worship, tend to choose candidates who follow the same religion. Respondents who claimed enough or very devout worship as much as $41.6 \%$, stated that the similarity of religion held by the candidates with him became one of his considerations in choosing candidates (Yustiningrum \& Ichwanuddin, 2015). In short, the psychological social approach explains what factors influence decisions Short-term elections or decisions taken in a short period of time, explained by the determinant triage, i.e. party identification, candidate orientation and political issue orientation. To make clear, Miller and Shanks argue that the idea as if in original conceptualization of party identification was, once formed, immutable to people's political experiences during their life as an adult, is a caricature, their view is 'closer to the revisionists'. The extreme revisionist view [...] that, in contrast, party identification is simply another political attitude, susceptible to influence and change by short-term phenomena, thoroughly endogenous to electoral behavior explanations. In this revisionist view party identification is primarily the assemblage consequence of issue or policy preferences held by voter prior to voting (Miller \& Shanks, 1996, p. 130). The most influential party identification reconceptualization role in shaping of voter's choice between candidates was developed by Fiorina's in study Retrospective Voting in American National Elections (1981). He finds that a model party identification is defined as 'the difference between an individual's past political experiences with two parties, perturbed by a factor, $y$, that represents effects not included directly in an individual's political experiences (e.g., parents' ID) (Fiorina, 1981, p. 89).

\section{Methodology}

This research uses descriptive approach analysis. The research is intended to provide an explanation of an event or a particular issue, which is already available information associated with symptoms or problems that are being investigated, so as to be able to supplement information in more detail and provide solutions resolving the issue, this research provides appropriate studies support the theory associated with these problems. Secondary data obtained through library research method sourced from literature books and journals related to public figures and identification of political parties in Indonesia. The analysis method uses a qualitative analysis approach to the research results conducted by previous researcher's books of literature and data taken from Regional Election Commission then researchers conducted a qualitative deepening of the analysis in accordance with researchers ability and understanding level in political party field. The research uses purposive sampling technique and the number of informants are PDIP's political party leaders in Subang and Cirebon Regency, Local House Representatives Leader and public figures, such as theologian, community leaders, and academician. In this research there are two types of data obtained by researcher in primary data in interviews form as the main to informants who have been determined. The research use triangulation of data to assure the data's validity.

\section{Results and Discussion}

The 1999 General Election was the first democratic election held after the New Order era. The national election results show PDIP as the winning party for the general election whose take 153 seats at House of Representatives. The 2004 elections, followed by 24 parties, resulted in a much more varied distribution of party-to-party power. The number of seats won was Golkar Party who has 133 seats following by PDIP with 108 seats in House of Representatives. The 2009 general election Democratic Party was the winner with 148 seats follows by Golkar Party and PDIP with108 and 59 seats, respectively. At the level of LHoR the situation was similar. In Subang and Cirebon Regencies the base of PDIP's constituent decline also happened significantly. Data taken from the Regional Election Commission showed a decline in PDIP dominance in seats distribution in LHoR in both regions. The analysis results show that when compared with the LhoR seats in 1999 general election it can be said that the number of PDIP seats is gradually decrease. The Table number 1 
and 2 show that PDIP member proportion in LHor getting lower, even though the number of parliamentary seats then added.

Table 1: Distribution of Seats in Parliament Participants General Election 2004-2014 in Subang and Cirebon Regencies

\begin{tabular}{llllllll}
\hline & & \multicolumn{3}{c}{ Subang Regency } & \multicolumn{5}{c}{ Cirebon Regency } \\
No. & Name of Political Parties & Year & & \multicolumn{5}{c}{ Year } & \\
& & $\mathbf{2 0 0 4}$ & $\mathbf{2 0 0 9}$ & $\mathbf{2 0 1 4}$ & $\mathbf{2 0 0 4}$ & $\mathbf{2 0 0 9}$ & $\mathbf{2 0 1 4}$ \\
\hline I. & PDIP & 14 & 14 & 10 & 14 & 14 & 11 \\
II. & Golkar & 13 & 6 & 7 & 10 & 6 & 6 \\
III. & PKS & 6 & 7 & 7 & 3 & 6 & 5 \\
IV. & PPP & 2 & 1 & 2 & 4 & & 1 \\
V. & PKB & 4 & 3 & 5 & 6 & 7 & 8 \\
VI. & PKPB & 2 & 2 & - & - & - & - \\
VII. & Demokrat & 2 & 9 & 5 & 6 & 7 & 5 \\
VIII. & PKPI & 1 & - & - & - & - & - \\
IX. & PAN & 1 & 3 & 3 & 2 & - & - \\
X. & PBB & - & - & - & - & 1 & 1 \\
XI. & PDK & - & 1 & - & - & - & - \\
XII. & PPRN & - & - & - & - & 1 & - \\
XIII. & Gerindra* & - & 3 & 5 & - & 3 & 6 \\
XIV. & Hanura** & - & 1 & 3 & - & 5 & 3 \\
XV. & Nasdem ${ }^{* * *}$ & - & - & 3 & - & - & 4 \\
& In Total & 45 & 50 & 50 & 45 & 50 & 50 \\
\hline
\end{tabular}

Sources : Regional Electoral Comission (KPUD), 2018

The data in Table 1 shows LhoR's PDIP dominance in 2004 general election. PDIP and Golkar Party controls the majority of LhoR seats in both regions. In 2009 general elections although PDIP still controls the majority of LhoR seats but the proportion is declining. It can be seen from the number of legislative seats that are relatively fixed. The 2014 election actually presents another surprise, where parliament seats distribution in both areas is evenly distributed. PDIP dominance is fading. Even Nasdem and Hanura as a new party were able to achieve significant votes so they could state their representatives in LHOR seats. From three general elections, it can be observed that in addition to PDIP seats tendency, the party forces distribution is much more varied at a local level.

The lower votes earned by PDIP are also followed by the lower number of citizen's political participation in general election. In Subang, the number of voter participation also decreased. Regional Election Commission indicates that in 2014 Presidential Election then a new participation reached 67.9 percent which is lower compared to 2009 general election which reach 76.36\%. In Cirebon Regency case, the political participation level is relatively low and allegedly related to community apathy and the Regional Election Commission socialization. Based on voter participation rate analysis in 2009 Election in this area reached $75 \%$. This means there are about 376,970 of 1,507,880 voters who did not uses their suffrage. This is a failure in encouraging people's political participation and political parties capabilities to transferring political education. In fact, the percentage is lower than presidential elections and Legislatives Election. Data taken from The Regent Election 2013 shows that in first round of participation was about 52.41 percent and in second round was about 46.29 percent. While the legislative election participation rate is higher 63.45 percent and the presidential election 61.26 percent. 
Table 2: Number of Legislators of PDIP in Subang and Cirebon Regency

\begin{tabular}{ccllll}
\hline \multirow{2}{*}{ No. } & \multirow{2}{*}{ Year } & \multicolumn{2}{c}{ Subang Regency } & \multicolumn{2}{c}{ Cirebon Regency } \\
& & Number & Persentage & Number & Persentage \\
\hline 1. & 1999 & 18 & 40,0 & 18 & 40,0 \\
2. & 2004 & 14 & 31,1 & 14 & 31,1 \\
3. & 2009 & 14 & 28,0 & 14 & 28,0 \\
4. & 2014 & 10 & 20,0 & 11 & 22,0 \\
\hline
\end{tabular}

Sources : Regional Electoral Comission (KPUD), 2018

The election figures strong factors makes PDIP strategy in maintaining constituent base in both research areas still dependent on the political party figures leaders. As a result, when there is an internal chaotic political party as happened in PDIP in Subang Regency then a bad image will be attached to the party and reduce a political party attractiveness in the constituents eyes. The figures strength is indicated by 2014 general election, the PDIP succed was even followed by popular candidates achievement, Mauarar Sirait who was able to collect the most of 74,410 votes. Sirait success overshadowed Primus Yustisio acquisition, a soap opera actress who became legislative House of Representative candidate from National Mandate Party by collecting 34,525 votes. Primus Yustisio appearance as a legislative candidate shows still strong figure on general election. This shows that political parties have failed to perform their functions as a political education means. At local level, the strong figure of Eep Hidayat as party leader of PDIP in Subang also raises the figures importance compared with the program.

The results of the discussion show that previous party leaders less use wide good communication and networking with local and community leaders. But in this present era, under a new leadership communication are getting better, result positives impressions in public. Approach done by the new party board is now better than previous, because current board is more willing to blend. Cadres also currently involved more by board in various party activities, including to be involved in the party board. The FGD results also show that relationships with current community leaders are being rebuilt, leaders are invited to various activities to build good communication. Likewise, routinely began to visit residents and participate in citizens activities. In addition, the board is also already visited some intellectual leaders, so not only community leaders. This is also justified by community leader Mr. Ajinto who stated that in a new board, communication with the character is also more frequent. In fact, they are also often involved in some party activities. Even further it is said that there are different approaches that have been done in each region, especially in maintaining political communication with the characters. It is arranged based on the demographic base in Subang Regency: the north and south are peasantry while in the middle is a trader and labors. It creates different approach pattern between those two areas.

The similar situation was true within internal PDIP in Cirebon Regencies. This strong figure is justified by the party leader of PDIP Cirebon Regencies. He acknowledged the party board relationship to community leaders were very well. Perhaps also because of position as Cirebon's LhoR Chairman result is easier for him to build good relationship and communication with local figures and community groups. As LhoR chairman also has advantage because it can always appear in various momentum, such as religious momentum as Islamic New Year Celebration event. Moreover, in legislative elections in 2009, PDIP pressed on to the cadre to win PDIP in Cirebon Regencies, registering several popular singer as vote receiver. In 2004 elections PDIP lost 4 seats from 18 seats in LhoR legislative elections in 1999, so that in 2009 general election, PDIP targets 24 seats in LHoR. Party elites as political producers must offer a better political offer or alternative through good party performance and programs and offer better candidates. A clean party image of corruption should also be enhanced. This can be seen from the regent case, Vice Regent and Chairman of LhoR Subang. All of whom must be hostile to each other and must both be held in jail due to allegations of corruption. As the result is PDIP votes dropped quite sharply. The similar case also occurred in Cirebon Regency. Mustofa who became Chairman of PDIP emerged as a figure that rescues the party after previous chairman trapped in corruption social assistance case. As a result, voters punish PDIP both areas in 2014 general election.

In ethnicity terms, Subang and Cirebon relatively homogeneous, i.e. dominated by Sundanese tribe. The rest is Cirebon. Sundanese are live in central and southern highlands and northern coastal region is a Javanese speaker of the Cirebon dialect, which is similar to brebes Banyumas dialect. From religious side, voters majority in 
Subang and Cirebon are Muslim, with few are Christian and Catholic. The ethnic homogeneity and religious composition in region is directly proportional to legislative candidates composition. All candidates are Muslim, and generally Sundanese and Javanese. From this side, the candidates actual battle to win voters sympathy becomes very hard, because all have the same opportunities. The electorate community in highlands of Subang and Cirebon have relatively traditional voter base. These areas tend to have strong ties to Sundanese culture and have a high degree of religiosity. Sundanese society has always had a religious typology, where they tend to like religious symbols. It is different from people on the north coast. In addition to religious factors, ethnic factors are not sufficiently large. This is because almost all couples already represent this ethnicity. In the end, as explained earlier, voters no longer consider this factor. All candidates have equal opportunity to get support from the Sundanese. With explanation above, it can be said that sociological factors become one of the factors that contribute in determine choosing behavior. However, this factor does not seem to be dominant things, because there is still a psychological factor to be explained in next section.

Psychological factors relate to party identity. Party identifications is a psychological component that will contribute to the party system stability in Indonesia, political parties continuity or stability can occur when voters identifying themselves with the party. If only a few have party identifications, then the party support continuity will be weak (Campbell, 1960). Many factors affect this, one of which is a party identifications reduction. Political parties are still considered more important and struggle for internal affairs, whereas political parties are a political communication tool and community aspirations channel. In every regional head electoral contestation, emerging figures from outside party which look more popular so have big chance to be elected as governor, mayor or regent. This force the party to accommodate figures and ignore its own cadres when its cadres are less popular, in fact some way it will disrupt the party internal stability. The party also seemed to get public figures outside politics, musical communities, regional entity communities and mass organizations in a successful team of regional head candidates, although it was legitimate and made the contest more interesting, but this is what makes more visible the political parties weakness role in obtaining the heart or perpetuating voices in community. One way of fixing this party identification is how PDIP improves the party's internal regeneration system. This is the reason for political parties without any improvement in significant recruitment pattern. In fact, by improving regeneration system, PDIP will get candidates of regional and state leaders from internal integrity and loyal to the party so that in itself people will come back to believe and feel identified with parties.

The psychological approach is involving candidate orientation and issue / theme orientation. In terms of candidate orientation, there is almost no legislative candidate based on issues orientation or theme to be fought for. The candidate's orientation is further related to issues or theme orientation. In terms of issues and themes, not yet visible candidates who are able to package it pretty well. Political parties are no longer a main reference for voters. Precisely a positive self-image built through outdoor media is now a key reference for voters. Seeing the character of West Java society is known to tend to be permissive and forgiving, and very happy when someone presents himself as a figure who cares, do good, look religious and so forth. This gap that seems to have not been maximally utilized by legislator candidates. But the figure factor also cannot be the only one who is relied upon. This should also be accompanied by a precise strategy of the campaign team to see market potential (voters) and use appropriate strategies, in accordance with the electorate community needs. And other things that also can not be underestimated is the winning team foresight. Comparing to the national election, it can be seen that there was similar situation. Thornley (2014) suggest that these elections stars were the candidates and not political parties. Surveys prior to the elections were more likely to vote based on specific candidate attributes than on the candidates party affiliation. It is clear revealed low levels of trust in political parties in general. Parties have work to do to regain the interest and faith of Indonesian voters.

\section{Conclusion}

Based on the research results that has been done by researchers, it can be drawn some conclusions. First, the lower voice obtained by PDIP is also accompanied by the lower number of citizen's political participation in general election. Secondly, the strong factor of the election figures makes PDIP strategy in maintaining constituent base in both research areas still dependent on the figures of political party leaders. Thirdly, it also shows that the political parties functioning has not yet functioned as a political education means. Fourth, a combination of psychological and sociological approach to voters is required. The party identification will be 
used as a political parties strategies to achieve victory in the elections. Political parties can draw on ideas, ideology, and other identities that later as a tie to communicate with their constituents that can be realized in the nationwide election victory. Party identification only can be run with adorable public figure. In this point of view, political party needs to deliver their political ideology and in the same time provide good public figure as vote receiver.

\section{References}

Almond, G. A. (1993). The Study of Political Culture. In: D. B. a. R. Rytlewski, ed. Political Culture in Germany. . New York: St. Martins Press, Inc.

Campbell, D. (1960). Blind variation and selective retentions in creative thought as in other knowledge processes. Psychological Review, 67(6), 380-400.

Fiorina, M. P. (1981). Retrospective Voting in American National Elections. New Haven: Yale University Press. Geertz, C. (1983). Islam Santri dan Priyayi Dalam Masyarakat Jawa. Jakarta: Pustaka Jaya.

Hamid, S. (2014). Jokowis Party Takes Lead in Indonesia's Elections, But Steep Road Ahead in Elections in Indonesia. Jakarta: The Asia Foundation.

Joyce, P. (2008). Teach Yourself Politics. London: McGraw-Hill.

Miller, W. E. \& Shanks, J. M. (1996). The New American Voter. Cambridge, Mass: Harvard University Press.

Mujani, S., Liddle, R. W. \& Ambardi, K. (2012). Kuasa Rakyat: Analisis tentang Perilaku Memilih dalam Pemilihan Legislatif dan Presiden Indonesia Pasca-Orde Baru. Jakarta: Mizan Publika.

Roth, D. (2009). Studi Pemilu Empiris: Sumber, Teori-teori, Instrumen dan Metode. Jakarta: Lembaga Survei Indonesia.

Simmel, G. (1989). Philosophie des Geldes. In: O. Rammstedt, ed. Georg Simmel Gesamtausgabe. Frankfurt am Main: Suhrkamp.

Thornley, A. (2014). Nine Takeaways from the Legislative Elections in Elections in Indonesia. Jakarta: The Asia Foundation.

Yustiningrum, R. E. \& Ichwanuddin, W. (2015). Partisipasi Politik dan Perilaku Memilih Pada Pemilu 2014. Jurnal Penelitian Politik, 12(1), 117-135.

\section{Newspaper and Website}

Pikiran Rakyat. PDIP dan Demokrat di LHOR Kab. Subang Kehilangan 4 Kursi. http://www.pikiranrakyat.com/politik/2014/04/23/278901/PDIP-dan-demokrat-di-LHoR-kab-subang-kehilangan-4kursi

Pikiran Rakyat. Perolehan Suara Pileg 2014 Kota dan Kab. Cirebon Geser Dominasi Parpol Besar.www.pikiranrakyat.com/politik/2014/04/23/278923/perolehan-suara-pileg-2014-kota-dan-kab-cirebon-geserdominasi-parpol+\&cd=6\&hl=id\&ct=clnk\&gl=id

Detiknews. Wabup Cirebon Gotas yang Buron Kasus Korupsi Resmi Diberhentikan.https://news.detik.com/berita-jawa-barat/d-3515427/wabup-cirebon-gotas-yang-

\section{Document} buron-kasus-korupsi-resmi-diberhentikan

Berita Acara Rekapitulasi Penetapan Perolehan Kursi LHOR Hasil Pemilihan Umum KPUD Subang Tahun 2004-2014 \& Berita Acara Rekapitulasi Penetapan Perolehan Kursi LHOR Hasil Pemilihan Umum KPUD Tahun 2004-2014. (Minutes of Recapitulation of Seat Seat Acquisition of LHOR, General Election Results of KPUD Subang Year 2004-2014 \& Minutes of Recapitulation of Stipulation of Seat of LHOR, Election Result of KPUD Year 2004-2014). 